\title{
GEOINFORMATICS TECHNOLOGIES FOR PRESERVATION OF CULTURAL HERITAGE, CASE STUDY, RÁKÓCZI-BÁNFFY CASTLE, URMENIȘ, BISTRIȚA NĂSĂUD COUNTY, ROMANIA
}

\author{
V.M. Rădulescu ${ }^{\text {a }}$, G.M.T. Rădulescu ${ }^{\text {a }}$, Sanda Naș ${ }^{\text {a }}$, A.T. Rădulescu ${ }^{\text {a }}$, M. Bondrea ${ }^{\text {a }}$ Corina \\ M. Rădulescu ${ }^{\text {b }}$
}

a Technical University of Cluj-Napoca, Faculty of Civil Engineering, Terrestrial measurements and Cadastre Department, 15 C. Daicoviciu Str., 400020, Cluj-Napoca, Romania, E-mails: mihai.radulescu@mtc.utcluj.ro, ${ }^{*}$ gheorghe.radulescu@ mtc.utcluj.ro, sanda.nas@mtc.utcluj.ro, adrian.radulescu@mtc.utcluj.ro, mircea.bondrea@mtc.utcluj.ro

${ }^{\mathrm{b}}$ Technical University of Cluj-Napoca, Faculty of Sciences, 76 Victoriei Str., 430122, Baia Mare, Romania, E-mail: corinam.radulescu@gmail.com

Received: 20.02.2021 / Accepted: 22.03.2021/ Revised: 18.04.2021 / Available online: 31.05.2021

DOI: 10.2478/jaes-2021-0006

KEY WORDS: Bánffy Castle; UAV aerial ground photogrammetry; laser scanning; Ground Control Point; Agisoft Photoscan.

\begin{abstract}
:
The paper presents an application of the methodology used in the paper "Synthetic analysis of geoinformatics technologies for cultural heritage conservation, methodological approach". The creation of the 3D model of the Rákóczi-Bánffy Castle in Urmeniş, Bistrița Năsăud County, was done by applying and integrating Terrestrial Laser Scanning (TLS) technologies and aerial photogrammetry performed with an Unmanned Aerial Vehicle (UAV). Agisoft Photoscan was used to compare the results and then they were compared with the images scanned using CloudCompare software. Thus, following the performance, with the help of the mentioned software, of a series of processing of the point cloud obtained, through the two imaging technologies, the error between the points belonging to the point cloud taken with UAV and the one taken with Laser Scanner was between 1 and 15 mm, the margin of error being acceptable for monuments without complex architectural details, so that the point cloud resulting from UAVs can be used successfully in this activity. The aim of the paper is to elaborate a geomatic methodology with an optimized cost-quality ratio, later replicable in the analysis of the current state of other constructions of the same type, knowing that over 600 castles in Transylvania alone are in a similar state, and such cases can be found in other Central European states as well.
\end{abstract}

\section{INTRODUCTION}

Ali Ulvi presents in his work (Ulvi, 2019) the importance of using Unmanned Aerial Vehicles (UAVs) in the documentation performed in the Cultural Heritage activity, because it produces 3D models, data and orthophotoplans that are of good quality and fidelity at low prices. This position is also supported in the works of other authors (Papakonstantinou et al., 2019; Brutto, Garraffa and Meli, 2014). Norzailawati and co-authors emphasize in their paper (Norzailawati et al., 2019), the importance of using drones in the planning and conservation of heritage cities in Malaysia.

With a history dating back to 2006 and a first edition published a year later, Historic England published in 2018 the work entitled 3D Laser Scanning for Heritage: Advice and Guidance on the Use of Laser Scanning in Archeology and Architecture (3D Laser Scanning for Heritage , 3rd ed), an important guide that provides the information needed to use laser scanning appropriately for heritage projects. Various authors offer in their works examples on the use of this technology in identifying, maintaining and preserving the cultural heritage built in Egypt, at the National Museum of Natural History, Smithsonian Institution, respectively in Saudi Arabia (Mohsin and Fanar, 2017; Wachowiak and Karas, 2009; Haddad, 2011).

Unmanned Aerial Vehicle (UAV) and Terrestrial Laser Scanning (TLS) have established themselves over time as the main technologies for investigating historical monuments through the possibility of creating a 3D model of the objective being studied (Tobiasz et al., 2019). The integration of the two technologies in different fields of activity, namely Geology and Forestry, were presented in the works of the authors Branko Kordic and Aicardi, I. (Branko et al., 2019; Aicardi et al., 2016), the documentation activity necessary for the restoration reconstruction-conservation, viewed comparatively UAV-TLS being approached in several works (Adamopoulos et al., 2017; Moussa, 2014; Eisenbeiss and Zhang, 2012).

\footnotetext{
* Corresponding author: Gheorghe M.T. Rădulescu, Professor PhD Eng., Faculty of Civil Engineering, Technical University of Cluj-Napoca, 15 C. Daicoviciu Str., 400020, Cluj-Napoca, Romania, E-mail: Gheorghe.Radulescu @ mtc.utcluj.ro.
} 
The Rákóczi-Bánffy Castle in Urmeniş (Figure 1.), Bistrița Năsăud County, being one of the 12 existing castles in the county, all being listed as monuments of national interest and some as being of worldwide importance. The architect of the building and the head of the construction works was a craftsman from Alba Iulia, Mátyás Fundáló (https://castelintransilvania.ro/castelul-banffy-urmenis-.html, http://monumenteuitate.org/ro/monument/88/Urmenis-Banffy) who built a two-storey building with a rectangular plan, oriented to the east - west and provided with a roof with four sloping sides. During the reign of György Rákóczi II, the owner of the castle changed. It first came into the possession of the Barcsai family, and later, after a long process, became the property of the Bánffy family (from Losoncz) and in the years 1667-1668, Dénes Bánffy modernized the castle (https://www.wikitree. com/wiki/B\%C3\%A1nffy-41).

In a first phase of documentation (stages 1) on the nature of the documentation necessary to start the steps needed to restore the circuit of such an objective we had a discussion with the representatives of the Pont Group from Cluj Napoca, a of such an objective we had a discussion with the representatives of the Pont Group from Cluj Napoca, the authors of an extensive monograph and analysis of the situation of castles in Transylvania(https://www.castelintransilvania.ro/pdf/STRATE GIA_CIT.pdf,).
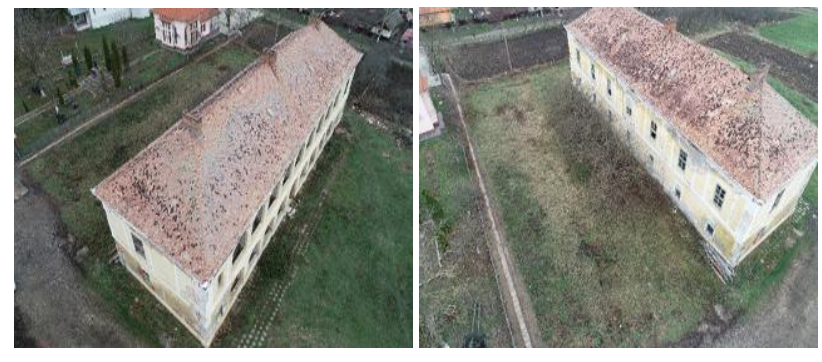

a.
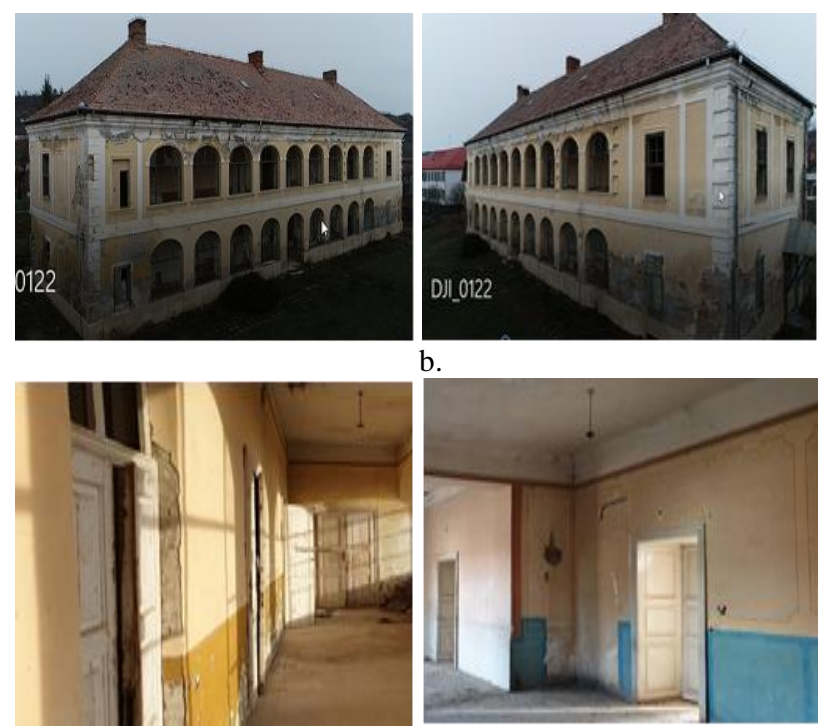

b.

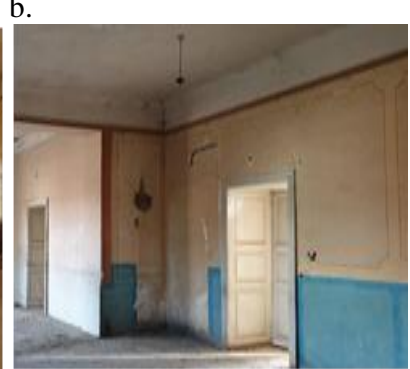

c.

Figure 1. Rákóczi-Bánffy Castle in Urmeniș, Bistrița Năsăud County, current state (December 2019), a. Drone view, b. Exterior on the four sides, c. Interior of the castle (Photo source: Authors)

\section{GEOMATIC METHODOLOGIES USED FOR THE CONSTRUCTION OF THE VIRTUAL MODEL OF THE STUDY OBJECTIVE}

The topographic survey works for the objective started by going through stages 1-9, presented in Figure 2, as follows (with reference to the order shown in the figure):

1. The S, T and D landmarks, presented in Table 1 and Figure 2, were identified;

2. The establishment of the 3D surveying and modeling of heritage objects (Remondino, 2011; Jo and Hong, 2019) consisted in choosing the UAV aerial photogrammetry (Adamil et al., 2019; Azzola et al., 2019; Barbetti et al., 2013) and laser scanning with fixed stations on the ground (Cintra and Gonçales, 2019; Hattab et al., 2017; Melvin and Basiliki, 2009; Nas et al., 2020; Radulescu et al., 2021);

3.a. Establishing planimetric support landmarks, considering the distance from the nearest landmark, respectively $S$ located more than $870 \mathrm{~m}$ from the objective, it was opted for creation of the planimetric network through GNSS technology ((Urbančič et al., 2019; Xu et al., 2014);

3.b. Establishing a leveling support landmark, landmark S was chosen, from which a middle geometric leveling route was performed in the circuit, granting elevation GCP P1;

In stage 4. Creation of the initial GNSS landmarks, P1-P2 was chosen as GNSS RTK support base, previously materialized in the field (https://historicengland.org.uk/images-

books/publications/3d-laser-scanning-heritage/heag155-3dlaser-scanning/), a Rover GNSS Leica smart antenna GS 08 plus GNSS and a Field Controller Leica Viva CS10 were used (Figure 2);

5. The establishment and materialization of the GCP was considered necessary for the georeferencing of the entire work, the formation of a GCP network consisting of nine points P1-P9, which materialized visibly in the field;

6. The thickening of the GCP Planimetric Network was done by a planimetric roading in the circuit, supported, compensated with a 7" Leica TS02 plus total station,

7. The distribution of the various elevations to the GCP planimetric landmarks was done with a Leica Sprinter 50 Digital level, through a middle geometric leveling roading, in circuit, supported on the initial elevation landmark P1;

- The above-mentioned topographic approaches resulted in a 8. Finalized GCP network, with X.Y.Z coordinates in the system (Table 1);

- $\quad$ For the 9th stage, "Chessboard" type landmarks were used, mounted on the façade of the objective in order to carry out the terrestrial photogrammetric survey, made with a Nikon D5100 digital camera 18-55 VR Kit; 


\begin{tabular}{|c|c|c|c|c|}
\hline \multirow{2}{*}{\multicolumn{2}{|c|}{ Points from the National Triangulation Network }} & $\mathbf{X}(\mathbf{m})$ & $\mathbf{Y}(\mathbf{m})$ & $\mathbf{Z}(\mathbf{m})$ \\
\hline & & \multicolumn{2}{|c|}{ Stereo 70} & $\frac{2(\mathrm{~min})}{\mathrm{RMN1975}}$ \\
\hline \multicolumn{2}{|c|}{ SCOROBOAIE-S (approx. $870 \mathrm{~m}$ northeast of castel) } & 586226.080 & 452276.319 & 494.019 \\
\hline \multicolumn{2}{|c|}{ TIGLA NEGMENILOR-T (approx. $3500 \mathrm{~m}$ southwest) } & 583779.308 & 448616.708 & 512.619 \\
\hline \multicolumn{2}{|c|}{ CASTEI HILL-D (approx. $3500 \mathrm{~m}$ southeast) } & 583622.454 & 454362.908 & 463.519 \\
\hline \multirow{9}{*}{ Ground Control Point } & P1 & 585735.307 & 451543.288 & 381.246 \\
\hline & $\mathbf{P 2}$ & 585753.723 & 451538.666 & 382.025 \\
\hline & $\mathbf{P 3}$ & 585766.065 & 451539.308 & 382.760 \\
\hline & $\mathbf{P 4}$ & 585782.078 & 451547.104 & 383.937 \\
\hline & P5 & 585782.759 & 451571.142 & 383.873 \\
\hline & P6 & 585773.126 & 451596.052 & 382.365 \\
\hline & P7 & 585752.423 & 451595.125 & 381.947 \\
\hline & P8 & 585738.462 & 451583.347 & 381.865 \\
\hline & P9 & 585735.418 & 451565.593 & 381.675 \\
\hline
\end{tabular}

Table 1. Points in the National Triangulation Network located in the area of operation and Ground Control Point coordinates - GCP, Bánffy Castle, Urmeniș

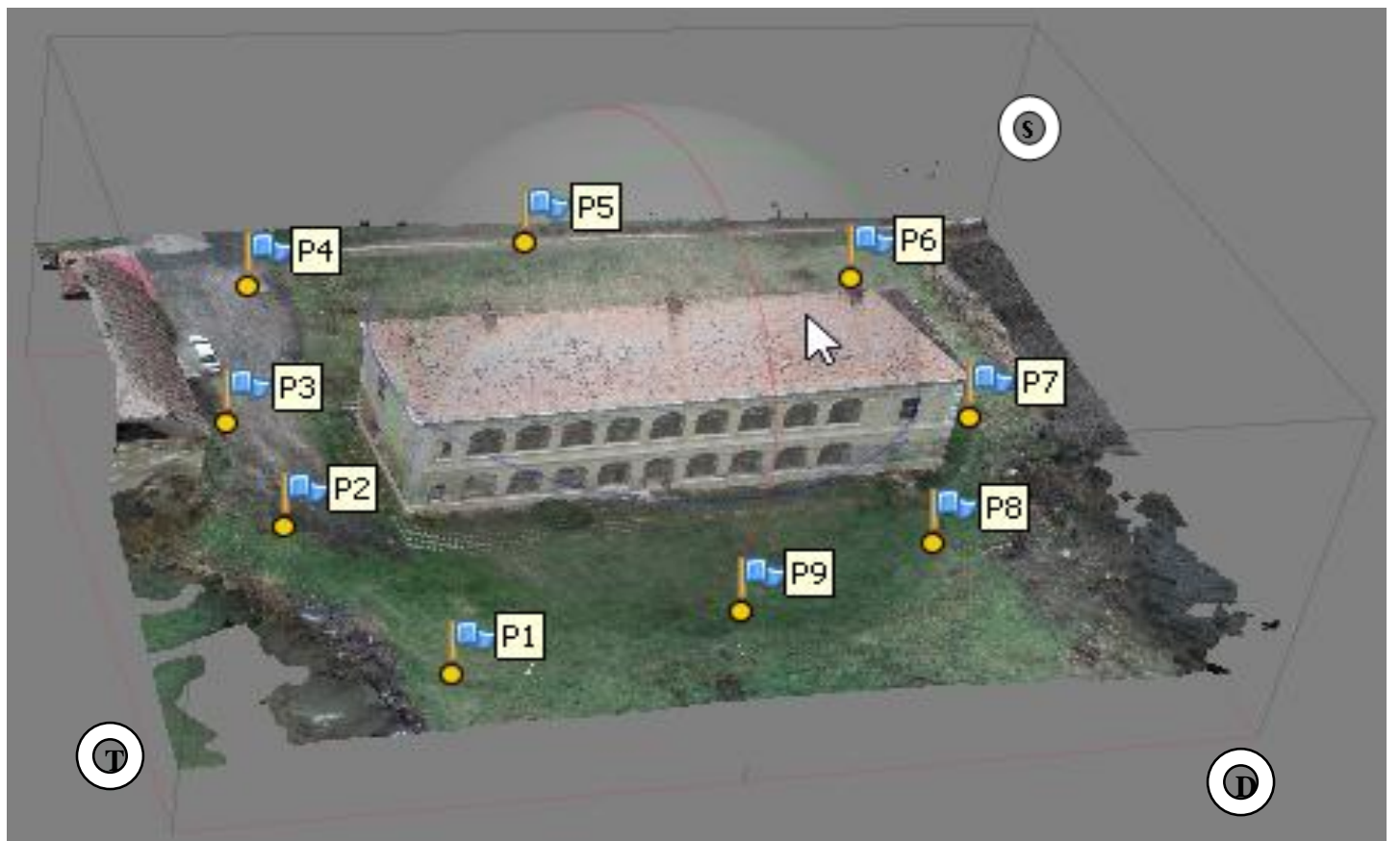

Figure 2. Position in the field, related to the studied objective of the S, T and D landmarks and Ground Control Points P1-P9

Field data was taken by UAV aerial photogrammetry, using a DJI Phantom 4 drone, with the following features: Camera Sensor: 1" CMOS; Resolution: 20 Mpixels, Lens: FOV 84; 8.8 $\mathrm{mm} / 24 \mathrm{~mm}$ (35 mm equivalent format: $24 \mathrm{~mm}$ ); $\mathrm{f} / 2.8-\mathrm{f} / 11$, auto focus at $1 \mathrm{~m}-\infty$, in two flight sessions, the first at a height of $30 \mathrm{~m}$ above the ground, to capture an overview of the objective being photographed in stereoscopic system, which resulted in a number of 120 photogrammes (figure $3 \mathrm{a}$., the second from a lower height, to obtain certain details not captured in the first session, taking 28 more photogrammes (figure 3b.). 18 fixed stations of known coordinates (figure 4a.) were chosen for the laser scan, of which 8 located at a greater distance and the next 10 near the scanned objective. The equipment's own software was used in the laser scan. Targets glued to the building façade were also used in order to frame the resulting points in the same projection system as the points taken with UAV (Stereo 70, Black Sea level 1975). Laser scanning was performed with a $\mathrm{Z}+\mathrm{F}$ scanner (Zoller + Frochlich) Imager 5010 with the following main features: Range 187 meters, Eye safe (laser class 1), Resistant against dust and water (protection class IP53), More than 1 million pixels/sec. maximum measurement rate, High accuracy, High measurement speed for all applications, Operating temperature from -10 to $+45^{\circ} \mathrm{C}$, Field-of-view $320^{\circ}$ x $360^{\circ}$, Dual-axiscompensator. Following the processing of UAV aerial photogrammes using Agisoft Photoscan software (https://www.agisoft.com/), a cloud of 5,894,000 points was generated (Figure 5a.). Z + F LaserControl ${ }^{\circledR}$ Office and Scout software was used to process the data resulting from the laser scan, and after clearing the cloud of noise points and those that covered areas that were not of interest for the case study, a number of 289,000,000 points resulted (Jo and Kim, 2017; Manajitprasert et al., 2019). The comparison and completion of the two point clouds resulting from UAV and 3D Scanner were performed using the CloudCompare software (Figure $5 b$.) (Http://www.cloudcompare.org/) implemented in the SfM algorithm. The accuracy of the 3D UAV-SfM model(Manajitprasert, Tripathi and Arunplo, 2019) was evaluated using 9 GCPs, evenly distributed in the study area, using the following equations (equations (1) to (3)): 


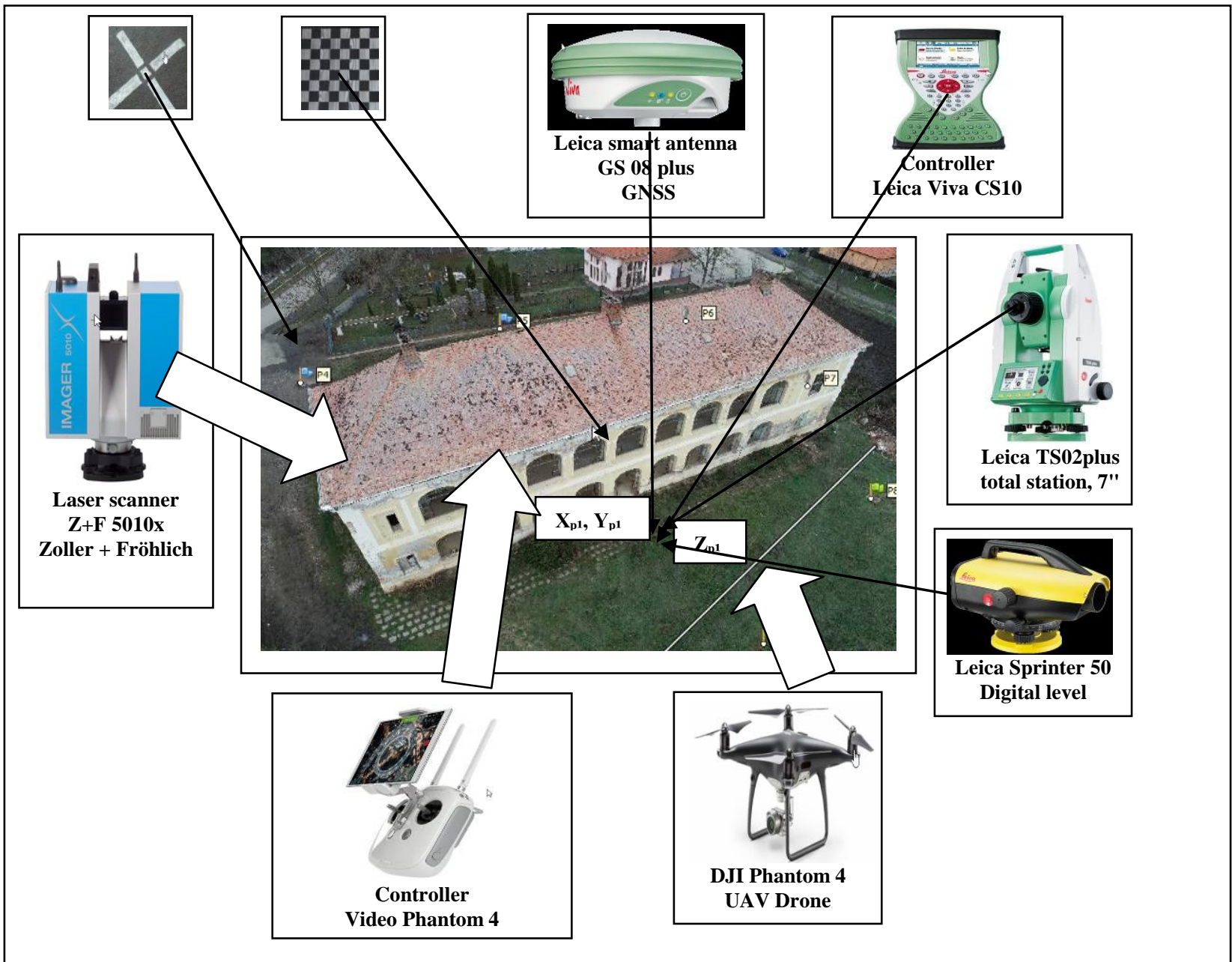

Figure 2. Rákóczi-Bánffy Castle in Urmeniş, Bistriţa Năsăud County, Stages of the process of taking the field data on the current state of the objective and the tools used

$$
\begin{aligned}
& R M S E=\sqrt{\frac{\sum_{i=1}^{n}\left(x_{R T K, i}-x_{\text {computed }, i}\right)^{2}}{n}} \\
& R M S E=\sqrt{\frac{\sum_{i=1}^{n}\left(y_{R T K, i}-y_{\text {computed }, i}\right)^{2}}{n}} \\
& R M S E=\sqrt{\frac{\sum_{i=1}^{n}\left(z_{R T K, i}-z_{\text {computed }, i}\right)^{2}}{n}}
\end{aligned}
$$

Where:

RMSE is the root-mean-square error;

$\mathrm{x}_{\text {computed,i }}, \mathrm{Y}_{\text {computed,i; }} \mathrm{z}_{\text {computed,i }}$ is the point coordinates in the UAV images;

$\mathrm{x}_{\mathrm{RTK}, \mathrm{i}} ; \mathrm{y}_{\mathrm{RTK}, \mathrm{i}} ; \mathrm{z}_{\mathrm{RTK}, \mathrm{i}}$ is the point coordinate measured from RTK;

$\mathrm{n}$ is the number of GCPs.

To align the point clouds and compare the errors, the point cloud resulting from the $3 \mathrm{D}$ Scanner was used as a reference over which the point cloud resulting from the UAV was manually aligned, in a first phase. The result was errors in the order of centimetres, due to the imperfect alignment of the point clouds. Then, using 4 common points chosen on the two compared entities, a second alignment was made automatically, generating, with the help of the software, a comparative image of the errors, shown in Figure 8b. It can be observed that for the studied objective the error between the points belonging to the point cloud taken with UAV and the one taken with Laser Scanner was between 1 and $15 \mathrm{~mm}$. After consulting with specialists in the reconstruction of heritage monuments, their opinion is that the margin of error is acceptable for monuments without complex architectural details, the example being the present case study, so that the point cloud resulting from UAV can be used successfully in this activity involving reconstruction and design for restoration-restoration and conservation of the studied objective. All this information can be the basis for moving to the design stage using CAD software (Rădulescu et al., 2021, stage 12 in Figure.3) and managing the activities for restoration and maintenance (Rădulescu et al., 2021, stage 13 in Figure 3), building the BIM and/or CHIS (Rădulescu et al., 2021, stage 14 in Figure 3). 

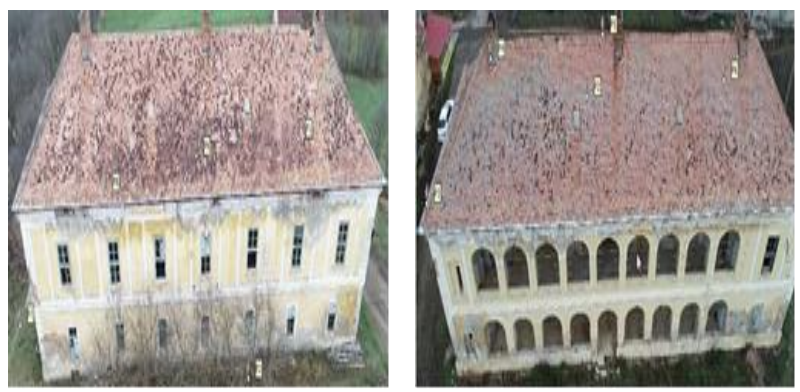

a.
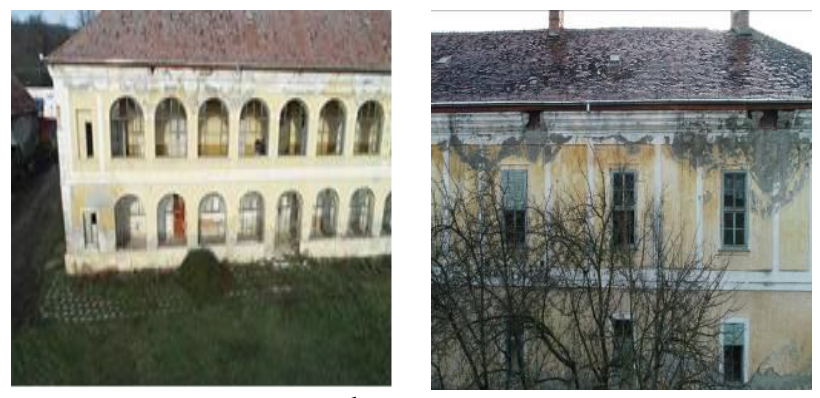

b.

Figure 3. Rákóczi-Bánffy Castle in Urmeniș, Bistrița Năsăud County, Aerial photogrammes taken from a drone, a. In the first shooting session, the two façades of the building, b. In the second shooting session (Image source: Authors)

To align the point clouds and compare the errors, the point cloud resulting from the 3D Scanner was used as a reference over which the point cloud resulting from the UAV was manually aligned, in a first phase. The result was errors in the order of centimetres, due to the imperfect alignment of the point clouds. Then, using 4 common points chosen on the two compared entities, a second alignment was made automatically, generating, with the help of the software, a comparative image of the errors, shown in Figure 8b. It can be observed that for the studied objective the error between the points belonging to the point cloud taken with UAV and the one taken with Laser Scanner was between 1 and $15 \mathrm{~mm}$. After consulting with specialists in the reconstruction of heritage monuments, their opinion is that the margin of error is acceptable for monuments without complex architectural details, the example being the present case study, so that the point cloud resulting from UAV can be used successfully in this activity involving reconstruction and design for restoration-restoration and conservation of the studied objective. All this information can be the basis for moving to the design stage using CAD software (Rădulescu et al., 2021, stage 12 in Figure 3) and managing the activities for restoration and maintenance (Rădulescu et al., 2021, stage 13 in Figure 3), building the BIM and/or CHIS (Rădulescu et al., 2021, stage 14 in Figure 3).
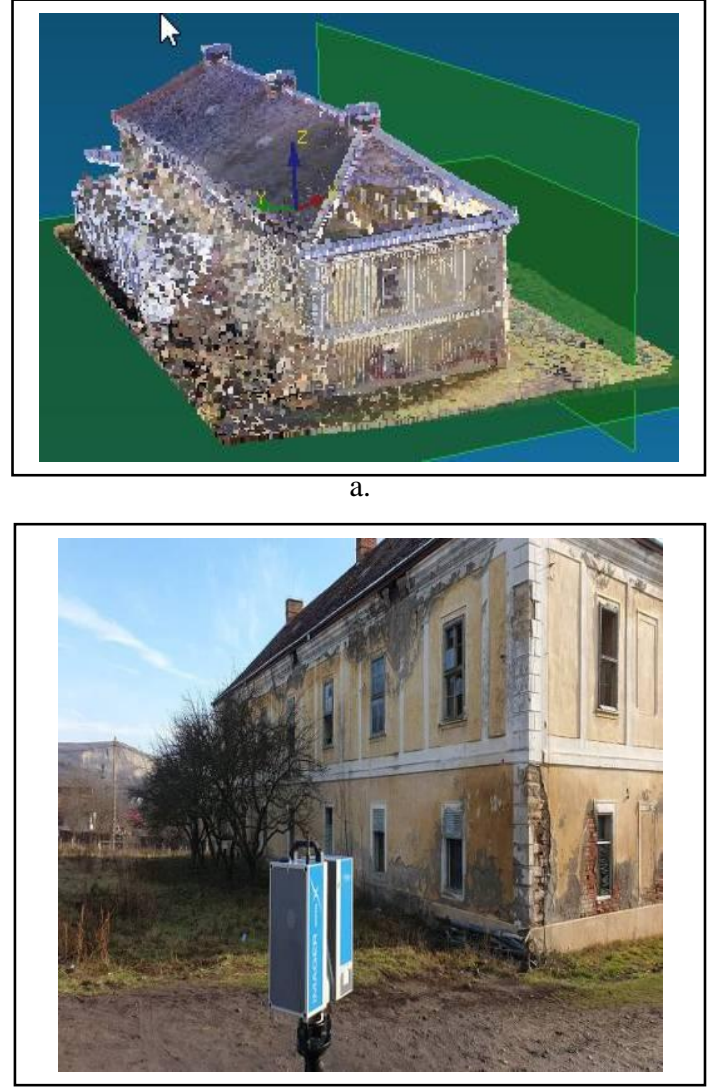

b.

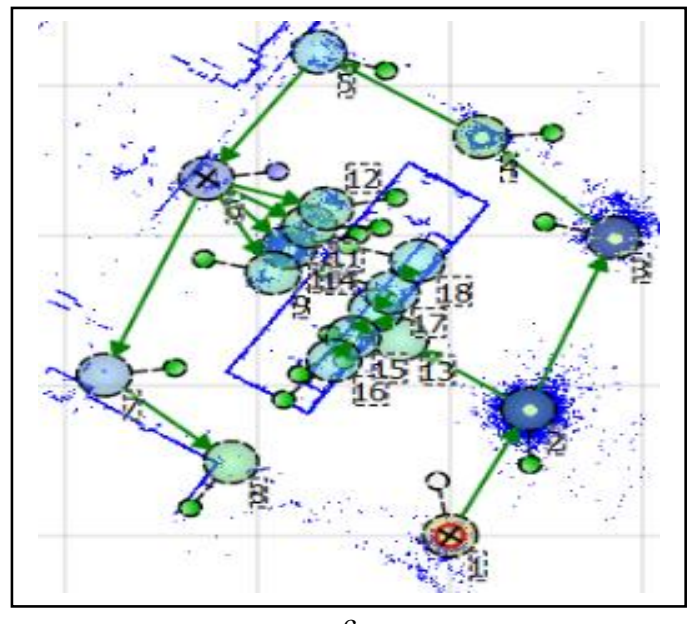

c.

Figure 4. Scanning details of Rákóczi-Bánffy Castle, a. Field position of the 18 scanning stations, b. Raw scanner image, c. Positioning of the Z + F 5010x scanner in the field, relative to the castle (Image source: Authors) 


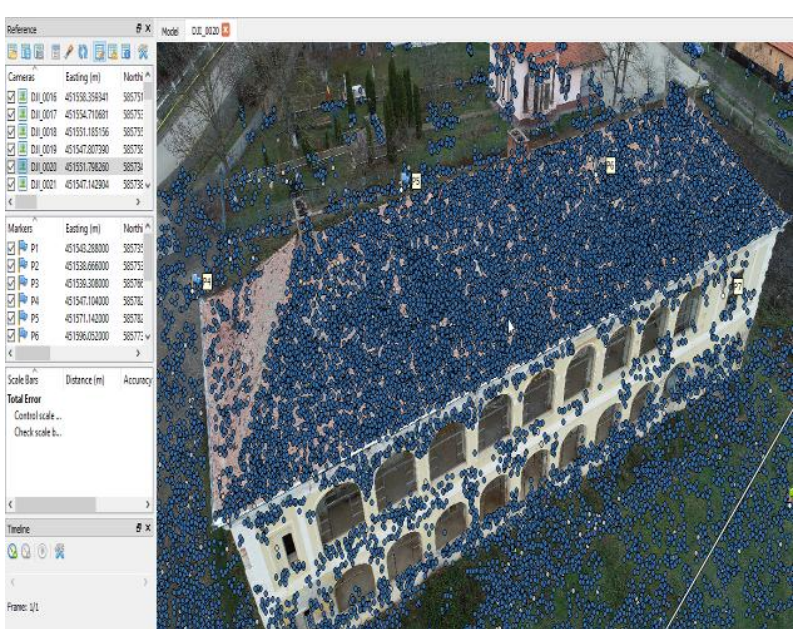

a.

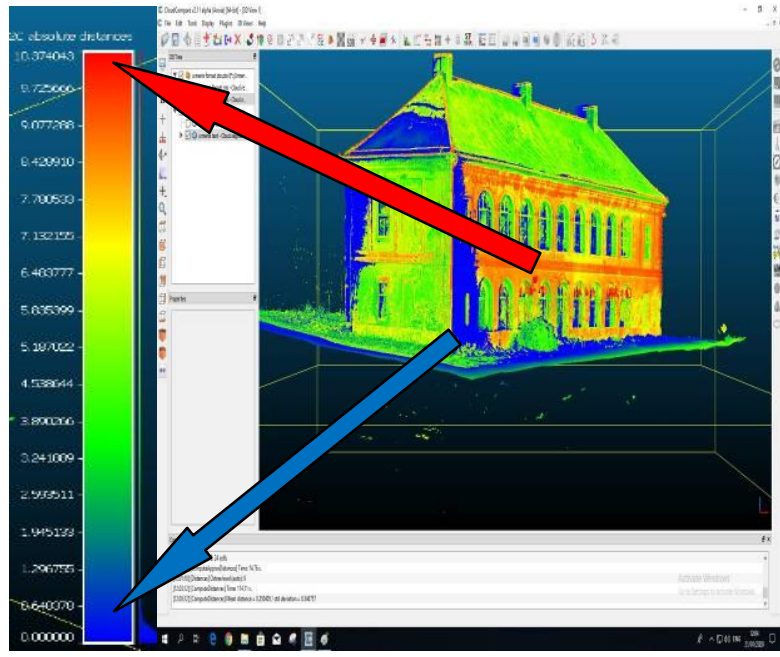

b.

Figure 5. Data processing, a. The point cloud resulting from the processing of UAV aerial photogrammes with Agisoft

Photoscan software, $b$. The result of comparing the point cloud resulting from aerial photogrammes with the point cloud given by laser scanning (Image source: Authors)

\section{CONCLUSIONS}

In order to build the 3D model of the studied monument, Rákóczi-Bánffy Castle, in Urmeniș, Bistrița Năsăud County, a total of 148 frames were made using UAV aerial photogrammetry technology and 18 laser scanning stations were performed.

The photogrammes were processed using Agisoft Photoscan and then they were compared with the images scanned by the CloudCompare software, resulting in differences of no more than $15 \mathrm{~mm}$.

Given the large volume of work required to highlight hundreds of monuments in various stages of degradation we can consider that outdoor and indoor stereoscopic aerial and terrestrial photogrammetric technology can meet most specific information requirements, including $3 \mathrm{D}$ modeling or $3 \mathrm{D}$ printing.
Another aim of the paper was to determine the level of accuracy required to operate UAV technology and where it becomes imperative to use laser scanning, given the high specific cost of the second technology compared to the first. The authors consider that laser scanning can be used for the studied object in specific areas with complex and intense architectural coverage. As a whole, the final products of UAV aerial photogrammetry are sufficient.

Rákóczi-Bánffy Castle, from Urmeniş, Bistrița Năsăud County, is in an advanced state of degradation, but is recoverable. However, millions of Euros are needed to fund this project, who will provide them and by what methods? The situation is similar in most of the other approximately 600 cases, in Transylvania alone.

\section{ACKNOWLEDGMENTS}

This project benefited from the support provided by Mapcad Proiect S.R.L. from Bistrița through the project "Researches regarding the use of UAV technology for the purpose of preserving and restoring historical monuments from Bistrița Năsăud County" which facilitated the documentation in order to carry out the researches that were the basis for the elaboration of the present work. Many thanks to Professor Călin Neamțu, from the Design Engineering and Robotics Department, Technical University of Cluj Napoca for his support in laser scanning of the targeted objectives and the development of the application system. Thanks also to the Pont NGO team from Cluj Napoca for their support.

\section{References:}

Adamil, A., Fregonese, L, Gallo, M., Helder, J., Pepe, M. and Treccani, D., 2019. Ultra light UAV systems for the metrical documentation of cultural heritage: applications for architecture and archaeology, The International Archives of the Photogrammetry, Remote Sensing and Spatial Information Sciences, Volume XLII-2/W17, 2019 6th International Workshop LowCost 3D - Sensors, Algorithms, Applications, 2-3 December 2019, Strasbourg, France.

Adamopoulos, E., Tsilimantou, E., Keramidas, V., Apostolopoulou, M., Karoglou, M., S. Tapinaki, S., Ioannidis, C., Georgopoulos, A., Moropoulou, A., Multi-Sensor Documentation of Metric and Qualitative Information of Historic Stone Structures, ISPRS Annals of the Photogrammetry, Remote Sensing and Spatial Information Sciences, Volume IV-2/W2, 2017 26th International CIPA Symposium 2017, 28 August-01 September 2017, Ottawa, Canada, Available from: https://www.researchgate.net/publication/319448392_MultiSen sor_Documentation_of_Metric_and_Qualitative_Information_o f_Historic_Stone_Structures [accessed Apr 12 2021].

Aicardi, I., Dabove, P., Lingua, A., Piras, M., Integration between TLS and UAV photogrammetry techniques for forestry applications, June 2016, iForest - Biogeosciences and Forestry 10(1), pp. 41-47, 2016, DOI: 10.3832/ifor1780-009.

Azzola, P., Cardaci, A., Mirabella Roberti, G. and Nannei, V.M., 2019. UAV Photogrammetry for Cultural Heritage Preservation Modelling and Mapping Venetian Walls of 
Bergamo, The International Archives of the Photogrammetry, Remote Sensing and Spatial Information Sciences, Volume XLII-2/W9, 2019 8th Intl. Workshop 3D-ARCH "3D Virtual Reconstruction and Visualization of Complex Architectures", 6-8 February 2019, Bergamo, Italy.

Barbetti, I., Felici, A., Magrini, D., Del Fa', R.M. and Riminesi, C., 2013. Ultra Close-Range Photogrammetry to assess the roughness of the wall painting surfaces after cleaning treatments, International Journal of Conservation Science, Volume 4, 2013, pp. 525-534.

Branko K.B., Luzar-Oberiter, B., Pikelj, K., Matoš, B., Vlastelica, G., Integration of Terrestrial Laser Scanning and UAS Photogrammetry in Geological Studies: Examples from Croatia, October 2019, Periodica Polytechnica Civil Engineering, 63(4), pp. 989-1003, DOI: 10.3311/PPci.14499.

Brutto, M. Lo., Garraffa, A., Meli, P., UAV Platforms for Cultural Heritage Survey: First Results, ISPRS Annals of the Photogrammetry, Remote Sensing and Spatial Information Sciences, Volume II-5, 2014ISPRS Technical Commission V Symposium, 23 - 25 June 2014, Riva del Garda, Italy, Available from: https://www.researchgate.net/publication/263409166_UAV_Pla tforms_for_Cultural_Heritage_Survey_First_Results [accessed Apr 11 2021].

Cintra, J.P., Gonçales, R., 2019. Applications of Laser Scan and drone aerial survey in museums, MUSEUMS/DOSSIER Interdisciplinary methods of analysis in museological collection, ANAIS DO MUSEU PAULISTA São Paulo, Nova Série, vol. 27, 2019, p. 1-27. e25d1.

Eisenbeiss, H., Zhang, L., Comparison of DSMS Generated From Mini UAV Imagery and Terrestrial Laser Scanner in a Cultural Heritage Application, ISPRS Commission V Symposium 'Image Engineering and Vision Metrology', IC WG I/V Autonomous Vehicle Navigation, September 2012.

Haddad, NA., From ground surveying to 3D laser scanner: A review of techniques used for spatial documentation of historic sites, Journal of King Saud University - Engineering Sciences, Volume 23, Issue 2, June 2011, Pages 109-118.

Hattab, A., Gonsher, I., Moreno, D. and Taubin, G., 2017. "Differential 3d scanning," IEEE Computer Graphics and Applications, vol. 38, no. 3, pp. 43-51, 2017.

Jo, Y.H., Hong, S. 2019. Three-Dimensional Digital Documentation of Cultural Heritage Site Based on the Convergence of Terrestrial Laser Scanning and Unmanned Aerial Vehicle Photogrammetry. ISPRS Int. J. Geo-Inf. 2019, 8, 53.

Jo, Y.H., Kim, J.Y., 2017. Three-Dimensional Digital Documentation uf Heritage Sites Using Terrestrial Laser Scanning and Unmanned Aerial Vehicle Photogrammetry, The International Archives of the Photogrammetry, Remote Sensing and Spatial Information Sciences, Volume XLII-2/W5, 2017 26th International CIPA Symposium 2017, 28 August-01 September 2017, Ottawa, Canada.
Manajitprasert, M.S., Tripathi, N.K. and Arunplo, S., 2019. Three-Dimensional (3D) Modeling of Cultural Heritage Site Using UAV Imagery: A Case Study of the Pagodas in Wat Maha That, Thailand, Appl. Sci. 2019, 9, 3640; doi:10.3390/app9183640.

Melvin, J.W., Basiliki, V.K., 2009. 3D Scanning and Replication for Museum and Cultural Heritage Applications, Journal of the American Institute for Conservation (JAIC) 48 (2009):141-158.

Mohsin M. Shanoer, Fanar M. Abed, Evaluate 3D laser point clouds registration for cultural heritage documentation, December 2017, Egyptian Journal of Remote Sensing and Space Science 21(3), DOI: 10.1016/j.ejrs.2017.11.007.

Moussa, W., Integration of digital photogrammetry and terrestrial laser scanning for cultural heritage data recording, Ph.D Thesis, 2014, Institute for Photogrammetry (Ifp), Stuttgart University.

Naș 1, S.M., Rădulescu, V.M., Rădulescu, G.M.T., Bondrea, M., Rădulescu, A.T., and Rădulescu, C.M., 2020, The Contribution of Geomatics Technologies in the Preservation of Cultural Heritage, 36th IBIMA Conference: 4-5 November 2020, Granada, Spain, ISBN: 978-0-9998551-5-7.

Norzailawati Mohd Noor, Ahmad Afiq Aiman Abdullah, Alias Abdullah, Illyani Ibrahim, Saadman Sabeek, 3D City Modelling Using Multirotor Drone For City Heritage Conservation, PLANNING MALAYSIA, Journal of the Malaysian Institute of $\begin{array}{llll}\text { Planners, } & \text { Vol } & 17 & \text { (2019), }\end{array}$ https://doi.org/10.21837/pmjournal.v17.i9.610.

Papakonstantinou, A.; Kavroudakis, D.; Kourtzellis, Y.; Chtenellis, M.; Kopsachilis, V.; Topouzelis, K.; Vaitis, M. Mapping Cultural Heritage in Coastal Areas with UAS: The Case Study of Lesvos Island. Heritage 2019, 2, 1404-1422. https://doi.org/10.3390/heritage2020089.

Rădulescu V.M., Rădulescu G.M.T., Naș S., Rădulescu A.T., Bondrea M., Corina M. C.M., 2021. Geoinformatics technologies for preservation of Cultural Heritage, Case Study, Rákóczi-Bánffy Castle, Urmeniș, Bistrița Năsăud County, Romania, JOURNAL OF APPLIED ENGINEERING SCIENCES.

Remondino, F., 2011. "Heritage recording and 3d modeling with photogrammetry and $3 \mathrm{~d}$ scanning," Remote Sensing, vol. 3, no. 6, pp. 1104-1138, 2011.

Tobiasz, A.; Markiewicz, J.; Łapiński, S.; Nikel, J.; Kot, P.; Muradov, M. Review of Methods for Documentation, Management, and Sustainability of Cultural Heritage. Case Study: Museum of King Jan III's Palace at Wilanów. Sustainability $2019, \quad 11, \quad 7046$. https://doi.org/10.3390/su11247046.

Ulvi, A. Importance of Unmanned Aerial Vehicles (UAVs) in the Documentation of Cultural Heritage. Preprints 2019, 2019100198 (doi: 10.20944/preprints201910.0198.v1).

Urbančič, T., Roškar, Ž, Kosmatin, F. and Grigillo, M., 2019. New Target for Accurate Terrestrial Laser Scanning and 
Unmanned Aerial Vehicle Point Cloud Registration. Sensors $2019,19,3179$

Wachowiak, Melvin J. and Karas, Vicky. 2009. "3D Scanning and Replication for Museum and Cultural Heritage Applications." Journal of the American Institute for Conservation. 48:141-158.

Xu, Z., Wu, L., Shen, Y., Li, F., Wang, Q. and Wang, R., 2014. Tridimensional Reconstruction Applied to Cultural Heritage with the Use of Camera-Equipped UAV and Terrestrial Laser Scanner. Remote Sens. 2014, 6, pp. 10413-10434.

***3D Laser Scanning for Heritage, (3rd ed), Advice and guidance on the use of laser scanning in archaeology and architecture, Published 8 February 2018, https://historicengland.org.uk/images-books/publications/3dlaser-scanning-heritage/.

https://www.agisoft.com/ [assessed on 14.04.2020].

https://www.castelintransilvania.ro/castele.html, [assessed on 23.03.2020].

https://www.castelintransilvania.ro/pdf/STRATEGIA_CIT.pdf, [assessed on 23.03.2020].

https://castelintransilvania.ro/castelul-banffy-urmenis-.html [assessed on 14.04.2020].

http://www.cloudcompare.org/ [assesed on 14.04.2020]. https://historicengland.org.uk/images-books/publications/3dlaser-scanning-heritage/heag155-3d-laser-scanning/ [assessed on 14.04.2020].

http://monumenteuitate.org/ro/monument/88/Urmenis-Banffy [assessed on 14.04.2020].

https://www.wikitree.com/wiki/B\%C3\%A1nffy-41 [assessed on 14.04.2020]. 